\title{
Manajemen Anestesi pada Pasien dengan Tumor Regio Pineal yang Menjalani Kraniotomi Pengangkatan Tumor dengan Posisi Duduk
}

\author{
Monika Widiastuti ${ }^{*}$, Dewi Yulianti Bisri ${ }^{* *)}$, M. Sofyan Harahap ${ }^{* * *}$, Syafruddin Gaus $\left.^{* * * *}\right)$ \\ "Departemen Anestesiologi Fakultas Kedokteran Universitas Pelita Harapan, Tangerang, ${ }^{* *}$ Departemen \\ Anestesiologi dan Terapi Intensif Fakultas Kedokteran Universitas Padjadjaran, Rumah Sakit Dr. Hasan Sadikin \\ Bandung, ${ }^{* * *}$ Departemen Anestesiologi dan Terapi Intensif Rumah Sakit Umum Pusat Dr. Kariadi, Semarang \\ ${ }^{* * * *}$ Departemen Anestesiologi,Terapi Intensif dan Manajemen Nyeri Fakultas Kedokteran Universitas \\ Hasanuddin-Makassar
}

\begin{abstract}
Abstrak
Tumor regio pineal memiliki insiden $0.4-1 \%$ dari tumor intracranial. Lokasinya yang dalam, di antara kedua hemisfer otak, berdekatan dengan batang otak dan hipotalamus menjadi tantangan bagi bedah saraf. Operasi dengan supracerebellar approach dalam posisi duduk adalah pilihan terbaik untuk mencapai lokasi. Posisi duduk juga memfasilitasi lapang operasi yang optimal dengan retraksi cerebellum minimal. Posisi duduk membawa tantangan tersendiri untuk dokter anestesi, dengan segala kompleksitas saat memposisikan pasien dan risiko komplikasinya. Venous air embolism adalah pertimbangan utama yang jika tidak terdeteksi dan ditangani dapat menyebabkan kolaps kardiovaskular dalam waktu singkat. Pasien laki-laki berusia 38 tahun datang dengan keluhan nyeri kepala berat dan penglihatan kabur sejak 4 bulan sebelum masuk rumah sakit. Hasil Magnetic Resonance Imaging menunjukkan adanya massa di regio pineal dengan edema perifokal, tanpa deviasi struktur midline. Pasien dilakukan kraniotomi pengangkatan tumor dalam posisi duduk. Operasi berjalan selama 10 jam dengan hemodinamika stabil dan tidak terjadi komplikasi, dalam anestesi umum dengan kombinasi intravena dan inhalasi. Prinsip ABCDE neuroanestesi, posisi duduk dan implikasinya, dan lokasi operasi yang sulit adalah pertimbangan-pertimbangan anestesi yang harus diperhatikan pada pasien ini. Evaluasi preoperasi yang baik, komunikasi dan koordinasi yang baik antara tim bedah dan anestesi sangat diperlukan untuk kelancaran dalam kraniotomi dalam posisi duduk.
\end{abstract}

Kata kunci: tumor regio pineal, kraniotomi posisi duduk, neuroanestesi, venous air embolism

JNI 2021; 10 (3): 193-205

\section{Anesthetic Management of Patient with Pineal Region Tumor Underwent Craniotomy Tumor Removal in Sitting Position}

\begin{abstract}
Incidence of pineal regio tumor is $0.4-1 \%$ of intracranial tumors. Its location which is buried between two cerebral hemispheres, close to brainstem and hypothalamus become a difficult challenge for the neurosurgeon. Surgery with supracerebellar approach in sitting position is the best method to access the lesion. Sitting position also facilitates the optimal visual field with minimal retractions. However, for anesthesiologist, sitting position is challenging since it has its own complexities during positioning the patient and the risk of complications. Venous air embolism is one of the main concern and if not detected early and treated appropriately would leads to cardiovascular collapse instantly. This is a case of a 38-year-old male with chief complaint of severe headache and blurred vision started 4 months before admission. The Magnetic Resonance Imaging showed a pineal region tumor with perifocal edema, without midline deviation. The patient underwent craniotomy tumor removal with sitting position. The procedure lasted for 10 hours and uneventful. The principle of $\mathrm{ABCDE}$ neuroanesthesia, sitting position and its implications, and difficult tumor location are some anesthesia considerations for this patient. A thorough preoperative evaluation, good communication and coordination between surgery and anesthesia team are needed for a smooth uneventful procedure performed in sitting position.
\end{abstract}

Key words: pineal regio tumor, craniotomy sitting position, neuroanesthesia, venous air embolism

JNI 2021; 10 (3): 193-205

This article is licensed under

Creative Commons Attribution-NonCommercial-ShareAlike 4.0 International License.

CMonika W, Dewi Yulianti B. M. Sofyan H, Syafruddin G

(2021) under the CC-BY-NC-SA license 


\section{Pendahuluan}

Tumor regio pineal memiliki insiden $0.4-1 \%$ dari tumor intrakranial di populasi dewasa dan 3-8\% pada anak. Gejala klinis dari tumor pineal minimal dan tidak spesifik. Gejala yang timbul diakibatkan dari efek massa atau hidrosefalus obstruktif. ${ }^{1}$ Pilihan terapi pada pasien dengan tumor regio pineal bervariasi, dapat berupa reseksi total, radioterapi, kemoterapi atau kombinasi. Mayoritas tumor di pineal memerlukan tindakan pembedahan. ${ }^{1}$ Tumor regio pineal yang terletak jauh di dalam pusat cranium dan dikelilingi oleh struktur anatomis penting, menjadi tantangan bagi dokter bedah saraf. Pengetahuan yang presisi tentang kompleksnya anatomi di regio pineal dan struktur-struktur yang harus dilewati untuk mencapai kelenjar pineal, sangatlah penting. Ada banyak pilihan approach yang dapat dilakukan selama pembedahan, namun yang terbaik yang digunakan adalah infratentorial supracerebellar dan occipital transtentorial. ${ }^{1,2}$

Dokter bedah saraf seringkali meminta pasien dioperasi dalam posisi duduk karena visualisasi lapang operasi yang optimal. Posisi duduk membantu pendekatan langsung ke supracerebellar ke area pineal dan vena cerebral dalam dapat mudah divisualisasi dan dihindari. Meskipun kranium yang dibuka minimal, lapang operasi cukup untuk visualisasi dan melakukan manuver operasi. Dengan melakukan approach ini, regio pineal dan ventrikel tiga dapat dengan jelas divisualisasi. ${ }^{1,2}$ Posisi duduk juga memperbaiki drainase vena dan liquor cerebrospinalis (LCS) yang dapat menurunkan tekanan intrakranial (TIK). Akan tetapi banyak komplikasi dari posisi duduk yang harus menjadi pertimbangan, antara lain hemodinamika yang tidak stabil akibat venous pooling di ekstremitas bawah, penurunan perfusi otak akibat efek gravitasi, pneumocephalus, hematoma subdural, kuadriplegia, makroglosia, kerusakan saraf akibat penekanan di pleksus brakialis dan sciatica, dan venous air embolism (VAE). ${ }^{3,4}$

Venous air embolism terjadi karena masuknya udara ke sistem vaskular, dapat terjadi kapanpun ketika terdapat hubungan antara lingkungan dan vena yang terbuka pada tekanan subatmosfer. Deteksi dini VAE penting untuk dilakukan karena VAE dapat mengobstruksi sirkulasi pulmoner yang menyebabkan gagal jantung kanan dan henti jantung. ${ }^{3}$ Prinsip airway, breathing, circulation, drugs, environment (ABCDE) neuroanestesi, posisi duduk dan segala komplikasinya, lokasi operasi yang sulit adalah beberapa pertimbangan anestesi yang harus diperhatikan pada pasien ini.4 Koordinasi dan komunikasi yang baik antara dokter bedah saraf dan anestesi dalam melakukan kraniotomi dengan posisi duduk harus dilakukan untuk dapat mengantisipasi kemungkinan komplikasi yang terjadi.

\section{Kasus}

Pasien laki-laki usia 38 tahun dengan tumor regio pineal yang menjalani kraniotomi pengangkatan tumor dalam posisi duduk.

\section{Anamnesis}

Pasien mengeluh sakit kepala berat dengan skala nyeri 7-9 dengan Numeric Rating Scale (NRS) sejak 4 bulan sebelum masuk rumah sakit (RS). Sakit kepala terus menerus sehingga mengganggu aktivitas, hanya membaik sesaat ketika beristirahat atau konsumsi obat analgetik paracetamol atau natrium diklofenak. Pasien juga memiliki keluhan pandangan kabur di kedua mata sejak 4 bulan sebelum masuk RS. Riwayat mual, muntah, kejang, penurunan kesadaran, kelemahan anggota gerak disangkal. Tidak ada gejala gangguan siklus tidur. Pasien baru pertama kali mengalami keluhan ini. Tidak ada riwayat serupa dalam keluarga. Untuk keluhan ini, pasien melakukan konsultasi ke dokter spesialis bedah saraf di RS lain dan disarankan melakukan pemasangan Ventriculo-peritoneal (VP) shunt. Namun karena gejala tidak membaik dan dari gambaran computed tomography scan (CT scan) gambaran hidrosefalus tidak membaik, dilakukan repair VP shunt 3 bulan sebelum masuk rumah sakit. Pascaoperasi VP shunt, sakit kepala pasien membaik derajatnya, namun sakit kepala masih dirasakan terus menerus, juga tidak ada perbaikan pada pandangan mata yang kabur, pasien melakukan ke konsultasi ke dokter bedah saraf di RS dan disarankan menjalani operasi 
pengangkatan tumor. Pasien tidak memiliki riwayat penyakit lainnya. Tidak ada obat-obatan rutin yang dikonsumsi oleh pasien. Pasien memiliki riwayat operasi kolesistektomi tanpa komplikasi.

\section{Pemeriksaan Fisik}

Pasien dengan berat badan $88 \mathrm{~kg}$ dan tinggi badan $175 \mathrm{~cm}$ (Indeks Massa Tubuh 29). Pemeriksaan fisik menunjukkan pasien compos mentis, tekanan darah (TD) 140/90 $\mathrm{mmHg}$, laju nadi $88 \mathrm{x} /$ menit, laju pernapasan $16 \mathrm{x} /$ menit, suhu tubuh $36,5^{\circ} \mathrm{C}$. Pemeriksaan jalan napas, dengan menggunakan kriteria penilaian jalan napas sulit LEMON yang meliputi look externally, evaluate 3-3-2, Mallampati, Obstruction or Obesity, and Neck mobility. Dari penilaian ini, pasien tidak memiliki kesulitan jalan napas dengan Mallampati I. Pemeriksaan toraks, abdomen, ekstremitas, dalam batas normal. Pemeriksaan neurologis dalam batas normal, tidak ada gangguan saraf kranial, defisit sensorik dan motorik, cerebellar ataxia juga tidak ditemukan. Pemeriksaan mata didapatkan gerakan bola mata bebas ke segala arah, pupil 3/3 dengan refleks cahaya $+/+$.

\section{Pemeriksaan Penunjang}

Hasil pemeriksaan Magnetic Resonance Imaging (MRI) kepala (Gambar 1) menunjukkan massa kelenjar pineal dengan edema perifokal yang pasca kontras tampak homogenous contrast enhancement, ukuran massa 3,9 x 3,0 cm (axial) $\mathrm{x} 3,7 \mathrm{~cm}$ (coronal), massa tampak menekan midbrain. Tidak tampak deviasi struktur midline. Tampak terpasang VP shunt dengan tip di sisi medial ventrikel lateralis kanan. Regio sella dan parasellar tanpa kelainan, juga orbita bilateral. Cerebellum menunjukkan struktur anatomis dan mielinasi yang normal. Hasil laboratorium pasien dalam batas normal tertera pada Tabel 1 . Hasil elektrokardiografi menunjukkan normal sinus ritme dengan laju nadi $66 \mathrm{kali} / \mathrm{menit}$. Hasil echocardiography menunjukkan hasil normal fungsi sistolik dengan fraksi ejeksi $74 \%$, ruang jantung normal, tidak ada abnormalitas regional wall motion, tidak ada pintasan intrakardiak, keempat katup jantung normal, tidak ada efusi pericardium atau vegetasi. Hasil CT scan thorax menunjukkan hasil normal.

\section{Pengelolaan Anestesi}

Selama persiapan untuk pembedahan elektif, pasien dipuasakan selama 6 jam dan diberikan cairan infus berupa $\mathrm{NaCl}$ 0,9\% $120 \mathrm{~mL} / \mathrm{jam}$. Kondisi pasien sebelum induksi anestesi adalah: E4M6V5 dengan pupil bulat isokor diameter 3 mm mata kanan dan kiri, tekanan darah 140/100 $\mathrm{mmHg}$, denyut jantung $80 \mathrm{kali} / \mathrm{menit}$, irama sinus, laju pernapasan $12 \mathrm{kali} /$ menit, $\mathrm{SpO}_{2} 100 \%$ tanpa suplemen Oksigen, suhu $36,5^{\circ} \mathrm{C}$.

\section{Induksi dilakukan dengan memposisikan}
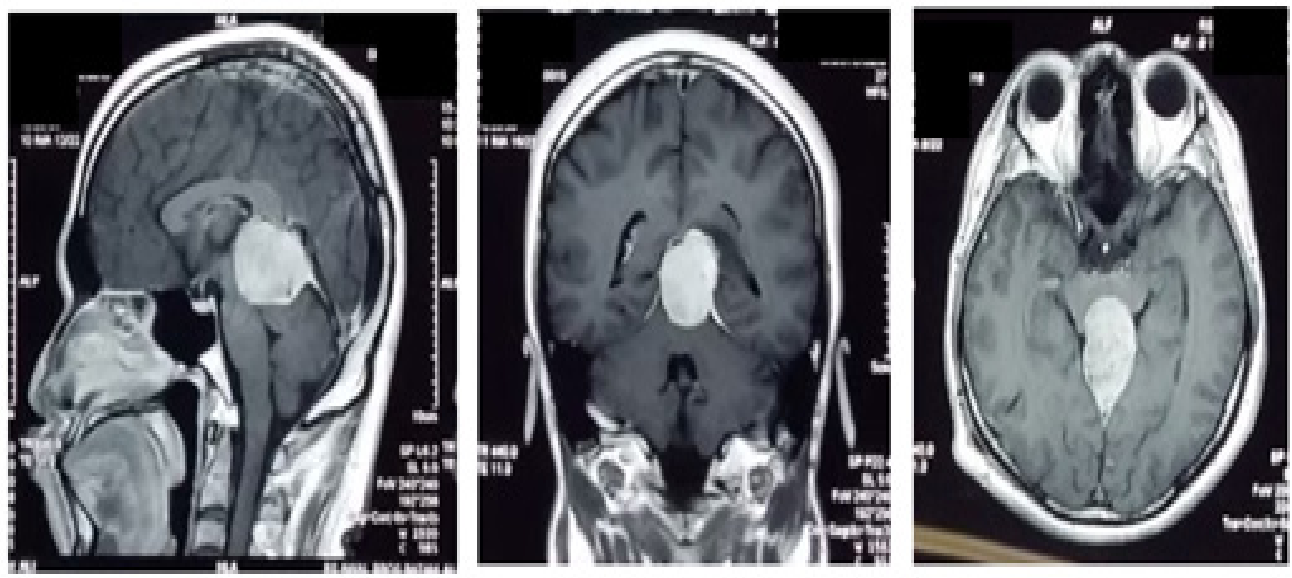

Gambar 1 (a),(b),(c) Potongan Coronal, Sagital dan Axial dari MRI Brain Pasien Menunjukkan Massa Kelenjar Pineal dengan Edema Perifokal yang Pasca Kontras Tampak Homogenous Contrast Enhancement, Ukuran Massa 3,9 x 3,0 cm (axial) x 3,7 cm (coronal), massa tampak menekan Midbrain. 
Tabel 1. Hasil Laboratorium Pasien

\begin{tabular}{lllllll}
\hline Parameter & Hasil & & & & Nilai Normal & Unit \\
\hline & $\mathrm{H}-1$ & $\mathrm{H} 0$ & $\mathrm{H} 1$ & $\mathrm{H}+5$ & & \\
Hemoglobin & 14.9 & & & 12.50 & $10.7-14.2$ & $\mathrm{~g} / \mathrm{dL}$ \\
Hematokrit & 44.4 & & & 36.90 & $31-43$ & $\%$ \\
Leukosit & 8.51 & & & 13.01 & $5-15.5$ & $10^{3} / \mu \mathrm{L}$ \\
Trombosit & 286 & & & 284 & $150-440$ & $10^{3} / \mu \mathrm{L}$ \\
Natrium & 140 & 141 & 139 & & $137-145$ & $\mathrm{mmol} / \mathrm{L}$ \\
Kalium & 3.9 & 3.5 & & & $3.6-5.0$ & $\mathrm{mmol} / \mathrm{L}$ \\
Klorida & 104 & 102 & 101 & & $98-107$ & $\mathrm{mmol} / \mathrm{L}$ \\
Ureum & 21 & & & & $<50$ & $\mathrm{mg} / \mathrm{dL}$ \\
Kreatinin & 0.88 & & & & $0.5-1.1$ & $\mathrm{mg} / \mathrm{dL}$ \\
PT Pasien & 10.70 & & & & $9.4-11.3$ & $\mathrm{detik}$ \\
INR & 1.03 & & & & & \\
APTT pasien & 23.10 & & & & $27.7-40.2$ & $\mathrm{detik}$ \\
Random Blood Glucose & 127 & 138 & 120 & & $<200$ & $\mathrm{mg} / \mathrm{dL}$ \\
\hline
\end{tabular}

tempat tidur dengan elevasi kepala $30^{\circ}$, obatobatan anestesi sebagai berikut: midazolam 5 $\mathrm{mg}$, fentanyl $100 \mathrm{mcg}$, propofol $150 \mathrm{mg}$ dan rocuronium $50 \mathrm{mg}$ intravena kemudian dilakukan intubasi menggunakan video laryngoscope dengan pipa endotrakhea reinforced ukuran 8.0 difiksasi pada kedalaman $22 \mathrm{~cm}$. Nasogastric tube (NGT) dan 18Fr kateter urine juga dipasang. Ventilator diatur dengan tidal volume $7 \mathrm{~mL} / \mathrm{kg} /$ menit, laju pernapasan $12 \mathrm{kali} / \mathrm{menit}$, Positive End Expiratory Pressure (PEEP) $0 \mathrm{cmH}_{2} \mathrm{O}, \mathrm{FiO}_{2}$ $50 \%$ dengan kombinasi $\mathrm{O}_{2}$ dan air. Dilakukan

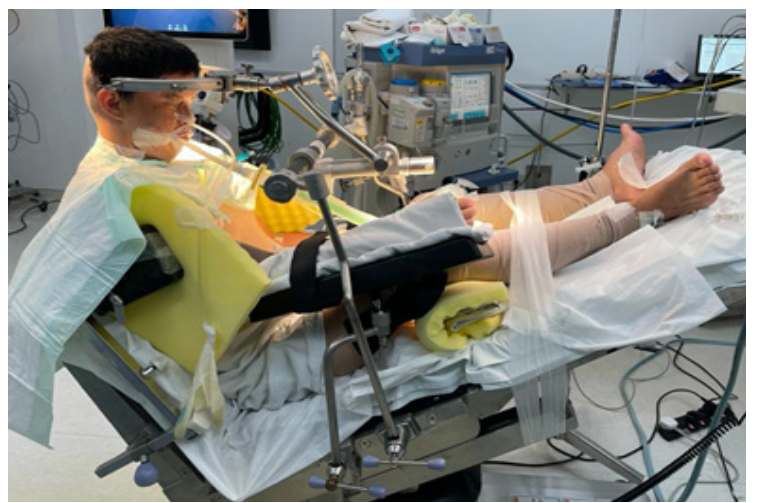

Gambar 2. Pasien dalam Posisi Duduk

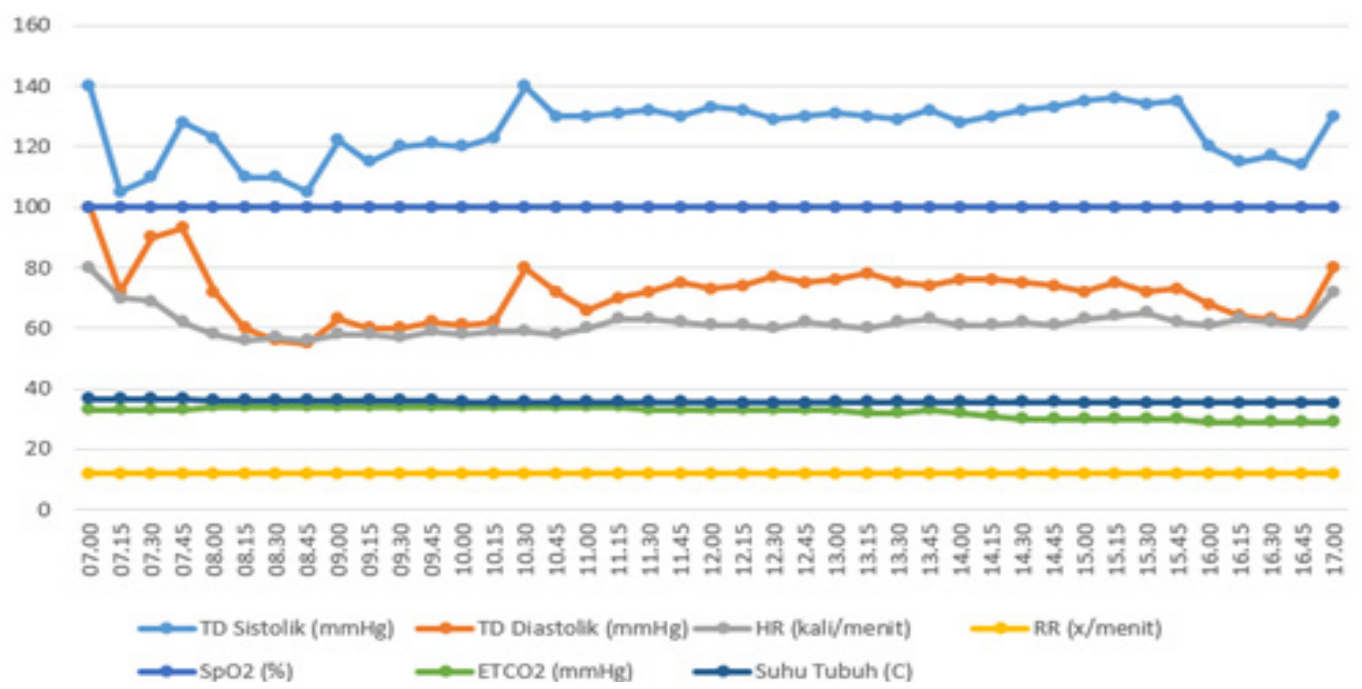

Grafik 1. Hemodinamika Pasien selama Prosedur 
pemasangan arteri line di arteri radialis kanan dan central venous catheter $7 \mathrm{Fr}$ di vena subclavia kanan. Dilakukan loading cairan $\mathrm{NaCl} 0.9 \%$ sebanyak $500 \mathrm{~mL}$ selama proses induksi hingga pemasangan monitor invasif. Pasien diposisikan dalam posisi duduk, dengan menggunakan Mayfield head rest, kepala difiksasi dengan 3 buah pin. Fleksi kepala dilakukan dengan tetap menjaga jarak dagu dan suprasternal notch $2,5 \mathrm{~cm}$. Lengan difleksi di siku dengan sudut $90^{\circ}$, disangga dan diberi bantalan. Punggung diposisikan sampai $60-70^{\circ}$ tungkai difleksi di panggul sampai setinggi dada pasien, kaki difleksi di lutut. kedua tungkai dipasang compression stocking, diberikan bantalan di bawah paha dan lutut. Setelah posisi pasien sesuai, semua pressure

Tabel 2. Kondisi Pasien Selama Perawatan di ICU

\begin{tabular}{|c|c|c|c|}
\hline & & Hari ke-1 & Hari ke-2 \\
\hline $\mathrm{F}$ & Feeding & Enteral $1800 \mathrm{kcal}$ & Enteral $1800 \mathrm{kcal}$ \\
\hline A & Analgesia & NRS 2/10, Morfin $1 \mathrm{mg} / \mathrm{jam}$ IV & NRS 4/10 \\
\hline \multirow[t]{2}{*}{$\mathrm{S}$} & Sedation & $\begin{array}{l}\text { RASS 2/6, Midazolam } 0.5 \text { mg/ } \\
\text { jam IV }\end{array}$ & Sedasi tidak diberikan \\
\hline & Sensorium & $\begin{array}{l}\text { GCS E1M1Vtube } \\
\text { Pupil 2/2 RC +/+ }\end{array}$ & $\begin{array}{l}\text { GCS E4M6V5 } \\
\text { Pupil 3/3 RC +/+ }\end{array}$ \\
\hline \multirow[t]{3}{*}{$\mathrm{T}$} & Tromboprophylaxis & $\begin{array}{l}\text { Compression stocking with } \\
\text { intermittent pneumatic device }\end{array}$ & $\begin{array}{l}\text { Compression stocking with } \\
\text { intermittent pneumatic device }\end{array}$ \\
\hline & Temperature & $36.1^{\circ} \mathrm{C}$ & $36.4^{\circ} \mathrm{C}$ \\
\hline & Tubes & $\begin{array}{l}\text { Pasien diekstubasi pada jam ke-5 } \\
\text { pascaoperasi }\end{array}$ & \\
\hline \multirow[t]{2}{*}{$\mathrm{H}$} & Head-up & $30^{\circ}$ & $30^{\circ}$ \\
\hline & Hemodynamic & $\begin{array}{l}\text { TD } 105-140 / 60-93 \mathrm{mmHg} \\
\text { Denyut jantung } 56-80 \mathrm{kali} / \text { menit } \\
\text { Laju pernapasan } 12 \mathrm{kali} / \text { menit } \\
\text { SpO2 } 100 \% \\
\text { Tanpa support hemodinamika }\end{array}$ & $\begin{array}{l}\text { TD } 110-140 / 58-90 \mathrm{mmHg} \\
\text { Denyut jantung } 60-80 \mathrm{kali} / \\
\text { menit } \\
\text { Laju pernapasan } 12 \mathrm{kali} / \text { menit } \\
\mathrm{SpO}_{2} 100 \% \\
\text { Tanpa support hemodinamika }\end{array}$ \\
\hline \multirow[t]{2}{*}{$\mathrm{U}$} & Ulcer prophylaxis & Esomeprazole $40 \mathrm{mg}$ & Esomeprazole $40 \mathrm{mg}$ \\
\hline & Urine output & $1-2 \mathrm{ml} / \mathrm{kg} / \mathrm{jam}$ & $1-2 \mathrm{ml} / \mathrm{kg} / \mathrm{jam}$ \\
\hline $\mathrm{G}$ & Glycemic control & GDS $138 \mathrm{mg} / \mathrm{dL}$ & GDS $120 \mathrm{mg} / \mathrm{dL}$ \\
\hline $\mathrm{S}$ & Spontaneous Breathing Trial & $\begin{array}{l}\text { Mechanical ventilator mode ASV } \\
100 \% \text {, PEEP } 5 \mathrm{cmH}_{2} \mathrm{O} \\
\text { Pasca ekstubasi, suplemen } \mathrm{O}_{2} \\
\text { nasal cannula } 3 \mathrm{~L} / \text { menit }\end{array}$ & $\begin{array}{l}\text { Suplemen } \mathrm{O}_{2} \text { nasal cannula } 3 \\
\mathrm{~L} / \text { menit }\end{array}$ \\
\hline B & Bowel movement & Bising usus + , tidak ada residu & Bising usus + \\
\hline \multirow[t]{2}{*}{ I } & Indwelling catheter & Arteri line + & Arteri line dilepas \\
\hline & Imbalance & $\begin{array}{l}\mathrm{Na} 141, \mathrm{~K} 3.5, \mathrm{Cl} 102 \\
\text { Balance cairan }-174 \mathrm{ml} / 7 \mathrm{jam}\end{array}$ & $\begin{array}{l}\mathrm{Na} 139, \mathrm{~K} 3.6, \mathrm{Cl} 101 \\
\text { Balance cairan }-528 \mathrm{ml} / 10 \mathrm{jam}\end{array}$ \\
\hline \multirow[t]{2}{*}{$\mathrm{D}$} & Drug de-escalation & $\begin{array}{l}\text { Morfin dan midazolam dihentikan } \\
\text { sebelum ekstubasi }\end{array}$ & Tidak ada \\
\hline & Delirium & Tidak ada & Tidak ada \\
\hline
\end{tabular}

Keterangan: $\mathrm{NRS}=$ Numeric rating scale, $\mathrm{IV}=$ intravena, $\mathrm{RASS}=$ Ramsay agitation sedation scale, $\mathrm{GCS}=$ Glasgow coma scale, $\mathrm{TD}=$ Tekanan darah, $\mathrm{GDS}=$ Gula darah sewaktu, $\mathrm{ASV}=$ Adaptive support ventilation, $\mathrm{PEEP}=$ positive endexpiratory pressure, $\mathrm{Na}=$ Natrium, $\mathrm{K}=\mathrm{Kalium}, \mathrm{Cl}=\mathrm{Chloride}$ 
points sudah terlindungi, transduser arteri line dipasang setinggi jantung pasien. Cairan rumatan intraoperasi adalah $\mathrm{NaCl} \quad 0.9 \% 360 \mathrm{~mL} / \mathrm{jam}$, transfusi sel darah merah diberikan sebanyak $223 \mathrm{~mL}$. Perdarahan intraoperasi sebanyak 700 $\mathrm{mL}$. Produksi urine $\pm 1 \mathrm{~mL} / \mathrm{kg} / \mathrm{jam}$. Durasi operasi selama $10 \mathrm{jam}$. Analgesia yang diberikan adalah parecoxib $40 \mathrm{mg}$ intravena dan untuk proteksi lambung diberikan esomeprazole $40 \mathrm{mg}$ intravena.

\section{Pengelolaan Pascabedah}

Pasien dipindahkan ke Intensive Care Unit (ICU), dengan kondisi hemodinamika tekanan darah 140/83 mmHg, denyut jantung $70 \mathrm{kali} /$ menit, laju pernapasan $12 \mathrm{kali} /$ menit, $\mathrm{SpO}_{2} 100 \%$. GCS E1M1Vtube dalam pengaruh obat, pupil 2/2 RC +/+. Pasien disambungkan ke ventilator dengan mode ASV $100 \%$, PEEP $5 \mathrm{cmH}_{2} \mathrm{O}$. $\mathrm{FiO}_{2} 50 \%$. Terapi tambahan di ICU ceftriaxone 2 gram intravena, lactulose $30 \mathrm{~mL}$ per NGT, dexamethasone $5 \mathrm{mg}$ intravena. Kondisi pasien selama 2 hari perawatan di ICU tertera pada Tabel 2. Pasien dipindahkan ke ruangan 1 hari pascaoperasi. Selama di ruangan, pasien stabil, nyeri kepala masih ada dengan NRS 3-4, namun membaik. Tidak ada komplikasi pascaoperasi. Pasien diperbolehkan pulang di hari ke-3 perawatan di ruangan.

\section{Pembahasan}

Kelenjar pineal merupakan struktur yang kecil dan terletak dalam di antara kedua hemisfer otak. Fungsi dari kelenjar pineal adalah sebagai organ fotoreseptor yang mensinkronisasi hormonhormon dan aktivitas neurobehavioral yang berhubungan dengan ritme sirkadian. Kelenjar pineal juga memiliki integritas dengan seluruh otak. ${ }^{1}$ Tanda dan gejala tidak spesifik, biasanya diakibatkan oleh efek masa dan hidosefalus obstruktif. Letak kelenjar pineal yang berdekatan dengan ventrikel ketiga dan keempat membuat efek massa yang menyebabkan hidrosefalus. Meskipun jarang, tumor ini menjadi tantangan bagi dokter bedah saraf karena letaknya yang jauh di dalam pusat kranium dan dikelilingi oleh struktur anatomis penting, menjadi tantangan. Ada banyak pilihan approach yang dapat dilakukan selama pembedahan, namun yang terbaik yang digunakan oleh dokter bedah saraf adalah infratentorial supracerebellar dan occipital transtentorial. Supracerebellar approach adalah yang dilakukan pada pasien ini, oleh karena itu dokter bedah saraf meminta untuk dilakukan posisi duduk. ${ }^{1,2}$

\section{Preoperasi}

Evaluasi yang dilakukan selalu meliputi anamnesis, pemeriksaan fisik, pemeriksaan penunjang. Evaluasi preoperasi selalu harus mempertimbangkan faktor-faktor yang berkontribusi terhadap komplikasi intraoperasi sehingga dapat dilakukan persiapan. ${ }^{5}$

\section{Anamnesis}

Pada anamnesis perlu ditanyakan mengenai kondisi pasien saat ini, apakah terdapat gejala peningkatan TIK, riwayat kejang atau defisit neurologis fokal: defisit motorik atau sensorik akibat penekanan massa. ${ }^{5}$ Pada pasien ini, terdapat gejala nyeri kepala berat, pandangan kabur, tapi tidak disertai gejala mual/muntah. Tidak terdapat riwayat kejang, defisit motorik dan sensorik. Pada pasien tidak terdapat gejala gangguan tidur.

Riwayat obat-obatan yang digunakan pasien seperti steroid (dexametahsone), obat kejang, mannitol, atau obat lainnya, juga perlu ditanyakan. Hal ini berhubungan dengan kontinuitas dari obat dan interaksi obat dengan agen anestesi. ${ }^{5}$ Pada pasien ini, tidak diberikan terapi rutin kortikosteroid atau antikejang. Juga tidak diberikan diuretik osmotik preoperasi. Status hidrasi pasien dievaluasi untuk melihat kecukupan asupan cairan dan efek pemberian diuretik. Hal lain yang perlu ditanyakan adalah riwayat operasi sebelumnya dari pasien, apakah pasien pernah mempunyai riwayat operasi bedah saraf (redo atau bukan). ${ }^{5}$ Pasien ini memiliki riwayat pemasangan VP shunt dan repair VP shunt 3 bulan sebelum masuk RS. Anamnesis juga dilakukan untuk mengetahui komorbiditas lainnya yang menyertai. Pada pasien ini tidak terdapat komorbiditas lainnya. ${ }^{5}$ Ataupun gejala lain yang berkaitan dengan tumor pineal; seperti gangguan siklus bangun-tidur atau gejala hipermelatoninemia (overproduksi dari melatonin 
yang dapat menyebabkan hiperhidrosis, anorexia nervosam polycystic ovarian syndrome) dan hipomelatoninemia (gangguan tidur, sindrom metabolik, intoleransi glukosa, resistensi insulin) ${ }^{5}$

\section{Pemeriksaan Fisik}

Pada pemeriksaan fisik selain tanda-tanda vital, jalan napas dan pemeriksaan umum lainnya. Pemeriksaan neurologis seperti pemeriksaan status mental, level kesadaran, adanya papil edema, respons Cushing (hipertensi, bradikardia), skor GCS, defisit fokal juga harus dilakukan. ${ }^{5}$

\section{Pemeriksaan Penunjang}

Pemeriksaan penunjang baik radiologis, laboratorium ataupun lainnya harus dievaluasi. Dari pemeriksaan radiologik (CT scan atau MRI), dievaluasi ukuran dan lokasi tumor (apakah dekat dengan pembuluh darah besar atau area eloquent otak), adanya efek massa berupa midline shift, herniasi temporal atau frontal, hilangnya basal CSF cisterna, hidosefalus. Pemeriksaan laboratorium untuk melihat hemoglobin, platelet, kadar elektrolit, fungsi ginjal, fungsi hati, fungsi koagulasi. ${ }^{5}$ Pemeriksaan elektrokardiogram dan rontgen atau CT scan thorax. Pada kasus ini, operator secara spesifik meminta untuk dilakukan dalam posisi duduk. Pemeriksaan echocardiography dilakukan pada pasien ini untuk menyingkirkan adanya kemungkinan ventriculoatrial shunt atau patent foramen ovale.

\section{Intraoperasi}

Monitor

Pada kraniotomi posisi duduk, selain monitor standar yang digunakan, juga diperlukan monitor tambahan seperti arterial line, central venous catheter (CVC), dan monitor untuk mendeteksi VAE. ${ }^{6}$ Seperti pada kebanyakan prosedur kraniotomi, arterial line dipasang pada pasien ini, yang menjadi pertimbangan adalah mengenai posisi transduser untuk arterial line. Pada pasien ini, transduser diletakkan setinggi jantung pasien. Ada yang menyatakan bahwa pada kraniotomi posisi duduk, transduser untuk arterial line tetap diletakkan pada level jantung. ${ }^{4}$ Namun, ada juga yang menyatakan untuk meletakkannya setinggi tragus atau setinggi meatus auditory externa atau basis cranii selama posisi dan selama prosedur. Hal ini dikarenakan, setiap perbedaan jarak antara jntung dan kepala sebesar $1 \mathrm{~cm}$, dapat terjadi perubahan tekanan sebesar $0,77 \mathrm{mmHg}$. $^{3}$

Namun, tidak ada bukti yang kuat yang menyatakan dimana level transduser yang lebih baik. ${ }^{4}$ Selama pembedahan dilakukan dengan rumatan propofol $50-75 \mathrm{mcg} / \mathrm{kg} / \mathrm{jam}$, rocuronium $0,01 \mathrm{mg} / \mathrm{kg} / \mathrm{menit}$, sevoflurane 0,7 volume $\%$. Selama operasi, hemodinamika pasien stabil dengan tekanan darah 105-140/60-93 $\mathrm{mmHg}$, denyut jantung 56-80 kali/menit dengan irama sinus. Dengan tetap menjaga MAP pasien dalam rentang autoregulasi, maka perfusi otak diharapkan tetap terjaga. Pemasangan CVC dapat memberikan akses vaskular juga untuk dapat mengaspirasi udara yang masuk, melalui atrium kanan. ${ }^{4,7}$ Central venous catheter harus selalu dipertimbangkan untuk dipasang pada pasien yang menjalani kraniotomi pada posisi duduk. Dibandingkan dengan kateter dengan satu lubang, memasang kateter dengan banyak lubang meningkatkan kemungkinan bahwa lubang akan berlokasi dimana udara berada. Penggunaan kateter dengan banyak lubang juga memfasilitasi aspirasi dengan volume yang lebih besar. Pemasangan CVC subclavia kanan dilakukan pada pasien ini untuk mengantisipasi terjadinya VAE. ${ }^{6,8}$

Monitor tambahan adalah monitor untuk mendeteksi terjadinya VAE. Deteksi VAE dapat dengan menggunakan beberapa modalitas, tidak ada satupun metode yang dapat memprediksi kejadian VAE secara akurat. Monitor yang dapat digunakan antara lain transesofageal echocardiography (TEE), precordial Doppler, pulmonary artery catheter (PAC) dan $\mathrm{ETCO}_{2}{ }^{9}{ }^{9}$ Di beberapa institusi di Jerman, TEE digunakan sebagai monitor rutin dan dipasang setelah induksi anestesi. Namu, TEE tidak $100 \%$ sensitif untuk deteksi PFO. ${ }^{2}$ Studi yang melibatkan 200 pasien yang dijadwalkan untuk operasi fossa posterior dalam posisi duduk menunjukkan, lima puluh dua pasien (26\%) mempunyai PFO dengan rate venous air embolism (VAE) 54\%. Hanya 1 pasien yang memiliki gejala signifikan namun tanpa sekuele neurologis. Kelemahan lain dari TEE adalah invasif dan tidak semua fasilitas 
memilikinya. ${ }^{10}$ Precordial Doppler merupakan alat yang sensitif dan tidak invasif untuk deteksi udara di atrium kanan, namun hal ini tergantung dari posisi pasien. Probe precordial diletakkan di sternum bagian kanan dan beberapa inci di atas xiphoid, dimana sinyal maksimal terdeteksi. Posisi probe dikonfirmasi dengan injeksi $5 \mathrm{ml}$ saline berisi udara melalui kateter atrium kanan dan mendengarkan perubahan karakteristik tonus Doppler. Hasil seringkali menjadi false positif jika udara tidak melewati ultrasonic beam (sekitar 10\% kasus). ${ }^{9}$ Pada kasus ini, yang digunakan adalah monitor $\mathrm{ETCO}_{2}$. End Tidal $\mathrm{CO}_{2}$ kontinyu merupakan monitor yang tidak invasif namun sensitif dan dapat dinilai secara kuantitatif. ${ }^{11}$ Turunnya $\mathrm{ETCO}_{2}$ menunjukkan meningkatnya gradien arterial-to-end-tidal $\mathrm{CO}_{2}$ gradient yang terjadi karena adanya udara intravaskular. Turunnya $\mathrm{ETCO}_{2}$ sebesar lebih dari $2 \mathrm{mmHg}$ secara tiba-tiba dapat menunjukkan terjadinya VAE. ${ }^{6}$ Faktor yang mempengaruhi akurasi kapnografi termasuk laju napas cepat, cardiac output rendah, dan penyakit paru obstrutif kronik. ${ }^{3,9}$ Selama operasi, tidak terjadi penurunan mendadak dari $\mathrm{ETCO}_{2}$ pada pasien ini.

\section{Posisi}

Manfaat dari posisi duduk masih menjadi kontroversi baik pada bedah saraf dan neuroanestesi. Posisi duduk memberikan banyak keuntungan bagi dokter bedah saraf namun membawa tantangan tersendiri bagi dokter anestesi. Banyak institusi yang tidak menyetujui operasi dalam posisi duduk karena komplikasinya. Beberapa faktor yang menentukan dilakukannya posisi duduk adalah risiko dan keuntungan, adanya kontraindikasi absolut, kenyamanan bagi dokter bedah saraf dan anestesi dan komunikasi tim yang baik sebelum dan selama operasi. ${ }^{3,10}$ Kontraindikasi pada posisi duduk absolut adalah adanya ventriculoatrial shunt yang paten, gangguan jantung berat, patent foramen ovale yang besar atau pulmonarysystemic shunt lainnya, tim anestesi atau bedah tidak familiar dengan posisi. Sedangkan kontraindikasi relatifnya adalah patent foramen ovale yang kecil, umur ekstrim, hipertensi tidak terkontrol, penyakit paru obstruktif kronis (tidak dapat kompensasi jika sampai VAE terjadi. ${ }^{4}$
Posisi duduk menjadi pilihan dalam operasi bedah saraf agar dapat mengakses fossa posterior dan cervical posterior. Meskipun pada operasi di fossa posterior, posisi pronasi atau lateral dapat juga menjadi pilihan, khususnya pada kasus ini, tumor regio pineal paling mudah diakses melalui approach supracerebellar dalam posisi duduk.

Beberapa keuntungan posisi duduk secara fisiologis dibandingkan posisi lainnya adalah adanya efek gravitasi memfasilitasi drainase dari LCS dari lapang operasi sehingga menurunkan TIK, perbaikan drainase vena serebal yang dapat menurunkan perdarahan dan kebutuhan transfusi darah, eksposure operasi yang optimal dan mengurangi durasi operasi jika dibandingkan posisi lainnya, akses operasi yang langsung pada struktur superfisial dan dalam pada fossa posterior, sehingga mengurangi retraksi jaringan dan risiko kerusakan saraf kranial, akses jalan napas, wajah dan dada pasien yang lebih baik, mengurangi tekanan intratorakal sehingga mengoptimalisasi respirasi dan memperbaiki ventilasi. Mengurangi risiko terjadinya tekanan intraocular yang dapat mengakibatkan post-operative visual loss (POVL). ${ }^{3,4,8}$ Cara memposisikan pasien ini, sesuai dengan cara memposisikan pasien yang direkomendasikan. Untuk posisi duduk, kepala pasien difiksasi menggunakan 3 pin head holder. Retraksi dari cervical cord dan obstruksi drainase vena dari kepala, wajah, dan lidah, harus dicegah dengan memposisikan kepala dengan menjaga jarak sekitar $2,5 \mathrm{~cm}$ antara dagu dan sternal notch. Hindari penggunaan oral airway yang besar atau bite block di faring untuk mencegah edema. Hindari rotasi leher yang berlebihan, posisi kepala tetap netral. ${ }^{4,8,9}$

Posisi bagian atas tubuh dan kaki dinaikkan dengan menekuk meja operasi menjadi posisi dimana panggul fleksi sebesar $90^{\circ}$. Kompresi abdomen, iskemia ekstremitas bawah, dan cedera saraf sciatic dicegah dengan menghindari fleksi berlebihan dari lutut ke dada (fleksi $30^{\circ}$ ). Pada area penonjolan tulang harus dipasang bantalan, siku dipasang bantalan untuk menghindari kontak dengan meja operasi atau penarikan dari plexus brakialis, dan kaki dijaga agar tidak terjadi penekanan di saraf common peroneal yang terletak 
di distal dan lateral dari fibula. Alat kompresi pneumatic intermittent atau compression stocking sebaiknya digunakan, seperti pada pasien ini. Hal ini bertujuan untuk membantu aliran balik vena sehingga mencegah episode hipotensi dan memperbaiki oksigenasi otak. ${ }^{3}$ Namun dengan banyaknya keuntungan ini, bukan berarti tanpa risiko. Penelitian-penelitian menyatakan terdapat 3 faktor risiko yang meningkatkan risiko komplikasi intraoperasi, yakni durasi operasi, komorbiditas pasien, dan posisi duduk. Posisi duduk memiliki risiko yang tinggi karena dapat menyebabkan kondisi yang mengancam nyawa, antara lain: $3,6,8$

- Efek gravitasi pada sistem vaskular yang menyebabkan pooling dari vena sehingga menurunkan preload dan pasien dapat mengalami hipotensi sistemik yang signifikan. Penurunan tekanan darah dapat mengakibatkan penurunan tekanan perfusi serebral, iskemia otak atau spinal dan bahkan dapat menyebabkan quadriplegia. Efek hipotensi dapat dicegah dengan pemberian bolus cairan sebelum memposisikan pasien dan memasang stoking kompresi setinggi paha atau memasang perban elastis pada ekstremitas bawah, dan memberikan vasopressor.

- Menyebabkan peningkatan resistensi vaskular sistemik dan pulmoner serta meningkatkan risiko kejadian tromboemboli.

- Kejadian tension pneumocephalus pascaoperasi sebesar 3\%. Hal ini disebabkan udara yang memasuki rongga epidural dalam jumlah besar sehingga dapat menyebabkan efek massa, berakibat hemiparesis, kejang atau herniasi otak. Nitrous oxide harus dihindari selama 14 hari pertama pasca kraniotomi. Risiko ini berkurang dengen pemasangan selang ventrikulostomi.

- Fleksi leher yang esktrim dimana dagu bersentuhan dengan dada, ditambah dengan penggunaan oral airway dapat menyebabkan obstruksi drainase vena dan limfatik, menyebabkan makroglosia yang signifikan yang dapat mengakibatkan obstruksi jalan napas dan hipoksia setelah ekstubasi. Hiperfleksi juga dapat mengakibatkan kuadriplegia. Posisi kepala dan leher yang ideal, yakni jarak 2,5 $\mathrm{cm}$ antara dagu dan sternum dengan penggunaan bite block yang lembut dapat mengurangi risiko ini.

- Neuropatiperiferdapatterjadi akibatkompresi iskemik atau peregangan berlebih dari saraf. Saraf yang terpengaruh terutama adalah saraf peroneal yang dapat menyebabkan drop foot. Saraf lainnya adalah plexus brakialis dan saraf sciatic. Terdapat laporan mengenai kuadriplegia akibat fleksi leher ekstrim pada kondisi hipotensi dan gangguan autoregulasi. Penggunaan bantalan pada titik-titik tekan sangat penting.

- Jika terjadi henti jntung maka resusitasi kardiopulmoner harus dilakukan pada posisi supinasi. Tidak seperti pada pasien yang dioperasi dalam posisi pronasi, resusitasi dapat dilakukan tanpa harus mengubah posisi pasien.

- Trauma lidah dan laring (termasuk trauma jika TEE digunakan)

- Kejadian venous air embolism yang mengancam jiwa

\section{Venous air embolism}

Venous air embolism (VAE) dapat terjadi pada operasi dengan lapang operasi di atas jantung, sehingga tercipta perbedaan tekanan antara lapang operasi dan jantung. Risiko ini bervariasi tergantung jenis operasi. Sinus vena yang noncollapsible yang terpapar selama operasi membuat risiko VAE tinggi pada kraniotomi posisi duduk. Dua faktor utama yang menentukan morbiditas dan mortalitas dari VAE ini adalah volume udara yang terjebak dan kecepatan dari akumulasi udara. Jumlah udara yang dapat menyebabkan emboli yang fatal masih diperdebatkan, namun dilaporkan $200-300 \mathrm{~mL}(3-5 \mathrm{~mL} / \mathrm{kg}) .{ }^{9}$ Venous air embolism terjadi akibat sistem vena yang terbuka dan adanya perbedaan tekanan vena. menurun di lapang operasi akibat efek gravitasi. Tempat tersering masuknya udara adalah di sinus vena yang tidak mudah kolaps karena menempel dengan dura, akan tetapi udara bisa masuk lewat vena manapun yang terbuka selama operasi. Vena yang terbuka menyebabkan tekanan vena negatif yang memfasilitasi masuknya udara.,

Insiden VAE bervariasi dari $1.6-50 \%$ tergantung dari metode deteksi yang digunakan oleh studi. ${ }^{4,11}$ 
Tabel 3. Derajat Venous Air Embolism dan Penanganannya ${ }^{4}$

\begin{tabular}{|c|c|c|}
\hline & Derajat Venous Air Embolism & Penanganan \\
\hline $\begin{array}{l}\text { VAE kecil } \\
(<10 \mathrm{~mL})\end{array}$ & $\begin{array}{l}\text { - Dapat terdeteksi dengan TEE atau precordial } \\
\text { Doppler. } \\
\text { - Tidak ada perubahan pada } \mathrm{ETCO}_{2}, \mathrm{SpO}_{2}, \mathrm{PAP} \text {. } \\
\text { - Biasanya TD dan HR tidak berubah. }\end{array}$ & $\begin{array}{l}\text { - Segera informasikan ke operator } \rightarrow \text { menyiram } \\
\text { lapangan operasi } \\
\text { - Kompresi vena } \\
\text { - Identifikasi serta menutup sumber masuknya } \\
\text { udara jika memungkinkan. }\end{array}$ \\
\hline $\begin{array}{l}\text { VAE sedang } \\
(10-50 \mathrm{~mL})\end{array}$ & $\begin{array}{l}\text { - Terdeteksi melalui TEE dan precordial Doppler } \\
\text { - } \downarrow \text { ETCO }_{2} \text { menurun } \\
\text { - } \uparrow \text { PAP } \\
\text { - Mulai muncul respons sistemik }\end{array}$ & $\begin{array}{l}\text { - Segera informasikan ke operator } \\
\text { - Hentikan operasi sampai VAE hilang. } \\
\text { - Oksigen } 100 \% \\
\text { - Cairan dan vasopresor (jika hipotensi) }\end{array}$ \\
\hline $\begin{array}{l}\text { VAE berat } \\
(>50 \mathrm{~mL})\end{array}$ & $\begin{array}{l}\text { - Terjadi perubahan besar pada monitor yang } \\
\text { digunakan. } \\
\text { - Terjadi disritmia, bradikardia, hipotensi, gagal } \\
\text { jantung kanan, dan henti jantung dapat juga terjadi. }\end{array}$ & $\begin{array}{l}\text { - Hentikan operasi } \\
\text { - Lakukan resusitasi } \\
\text { - Posisi Trendelenburg atau left lateral decubitus. } \\
\text { - Jika terpasang CVC, maka lakukan aspirasi udara } \\
\text { yang masuk ke jantung. } \\
\text { - Vasopresor }\end{array}$ \\
\hline
\end{tabular}

Namun sebagian besar kejadian VAE yang terdeteksi dilaporkan tidak relevan secara klinis. Pada Tabel 3 terdapat skala yang digunakan untuk menentukan derajat VAE beserta penanganannya. ${ }^{4}$ Venous air embolism dapat menyebabkan morbiditas dan mortalitas yang serius akibat hipotensi dan kolaps kardiovaskular (akibat obstruksi aliran darah ke jantung kanan dan hipertensi pulmoner) dan emboli paradoksikal sistemik melalui shunt intrakardiak atau intrapulmoner yang dapat mengakibatkan stroke dan iskemia arterial. Deteksi awal VAE sangat penting untuk menghentikan masuknya lebih banyak udara. ${ }^{9}$ Idealnya TEE dan precordial Doppler digunakan, namun karena keterbatasan fasilitas hal ini tidak dapat dilakukan.

\section{Pilihan Anestesi}

Untuk obat-obatan anestesi, tidak ada rekomendasi jenis anestesi terbaik untuk posisi duduk, namun anestesi intravena lebih disarankan. ${ }^{8}$ Penggunaan $\mathrm{N}_{2} \mathrm{O}$ ada posisi duduk masih menjadi kontroversi. $\mathrm{N}_{2} \mathrm{O}$ meningkatkan ukuran dari gelembung udara intravaskular jika emboli udara terjadi. Penelitian random prospektif pada pasien yang memerlukan operasi fossa posterior atau cervical menunjukkan bahwa $50 \% \mathrm{~N}_{2} \mathrm{O}$ tidak memberikan efek signifikan terhadap kejadian atau keparahan dari VAE jika $\mathrm{N}_{2} \mathrm{O}$ dihentikan ketika udara terdeteksi pada ultrasonography Doppler. ${ }^{9}$ Akan tetapi ada juga studi yang menyatakan untuk tidak menggunakan $\mathrm{N}_{2} 0$ karena sifatnya yang dapat berdifusi ke rongga kosong sehingga memperberat terjadinya pneumocephalus dan jika terjadi VAE akan membuat VAE membesar. Pada kasus ini tidak digunakan $\mathrm{N}_{2} \mathrm{O}$, kombinasi Oksigen dan air digunakan untuk memberikan $\mathrm{FiO}_{2}$ 50\% kepada pasien. ${ }^{4,8}$ Banyak teknik dan agen anestesi yang digunakan pada operasi bedah saraf pada posisi duduk. Apapun pilihannya, yang terpenting adalah tujuan dari neuroanestesi terpenuhi, yakni, lapang operasi yang tenang, TIK yang menurun, CPP adekwat, dan tekanan ventilasi yang rendah. ${ }^{4}$ Pada kasus ini digunakan kombinasi intravena dan inhalasi sevoflurane dengan MAC kurang dari 1.

\section{Manajemen Pernapasan}

Ventilasi mekanik diatur untuk menjaga pasien dalam kondisi normokapnia $\left(\mathrm{ETCO}_{2}\right.$ sekitar $35 \mathrm{mmHg}$ ). Pada kasus ini disarankan untuk menjaga $\mathrm{PaCO}_{2}$ yang lebih tinggi daripada kasus 
tumor kebanyakan dikarenakan TIK pada posisi duduk lebih rendah. ${ }^{4,8}$

\section{Cairan Intraoperasi}

Evaluasi status hidrasi pasien juga penting dilakukan karena saat posisi duduk, efek gravitasi akan membuat darah lebih banyak di ekstremitas bawah sesuai efek gravitasi. ${ }^{6,8}$, Pemberian loading cairan sebelum posisi duduk dapat membantu mencegah hipotensi., seperti pada pasien ini. Namun, jika tidak membaik maka dapat diberikan vasopressor berupa ephedrine atau phenylephrine.

\section{Pascaoperasi}

Komplikasi

Meskipun secara teoritis, terdapat risiko komplikasi jalan napas dalam bentuk edema jalan napas, namun beberapa laporan menunjukkan hal ini jarang terjadi. Perhatian lain pascaoperasi meliputi neuropati perifer, kuadriplegia, pneumocephalus. ${ }^{4,6}$ Kuadriplegia yang tidak bisa dijelaskan diaporkan pernah terjadi pasca posisi duduk. Hal ini disebabkan oleh fleksi leher dan obstruksi pembuluh darah selama operasi. Karena itu posisi kepala netral dan menjaganya agar tidak terlalu fleksi (jarak sternal notchdagu 2,5 cm) harus dijaga. Makroglosia, trauma di daerah mulut dan pembengkakann pada faring dilaporkan pada beberapa kasus dengan durasi operasi yang panjang. Penggunaan TEE sebagai monitor tambahan juga menambah risiko terjadinya trauma. ${ }^{4,6,8}$ Insidens dari pneumocephalus dilaporkan sebanyak 100\% untuk pasien yang menjalani operasi dalam posisi duduk, $72 \%$ untuk pasien yang menjalani operasi dalam posisi park-bench (semiprone lateral), dan $57 \%$ pada pasien dengan posisi pronasi. Pneumocephalus biasanya asimtomatik dan hilang dengan sendirinya. Akan tetapi, tension pneumocephalus dapat menyebabkan terjadinya defisit neurologis. Penanganannya suportif, termasuk pemberian Oksigen $100 \%$ dan pada kasus berat, pembuangan gas dengan aspirasi atau membuka ulang dura. ${ }^{7}$

\section{Emergence}

Tujuan anestesi selama periode emergence pascaoperasi adalah untuk mencegah peningkatan tekanan darah mendadak, pulih sadar cepat, kembalinya kekuatan motorik serta mengurangi batuk dan mengedan. Pada neuroanestesi, pasien dapat diekstubasi secara langsung ataupun tidak langsung dan hal ini memiliki pertimbangan serta pro dan kontra masing-masing. Keputusan ini didasari oleh kondisi pasien, jenis, lama dan manipulasi selama operasi. ${ }^{12,13}$ Ekstubasi awal atau yang disebut teknik fast track mulai digunakan pada pasien yang menjalani neuroanestesi. Keuntungan melakukan teknik ini adalah status neurologis pascaoperasi dapat segera dievaluasi, mengurangi kejadian hipertensi dan pelepasan katekolamin, pasien dapat terhindari dari komplikasi penggunanan ventilasi mekanis dan perawatan di ICU serta biaya yang lebih hemat. Akan tetap di luar keuntungan ini perlu diingat bahwa banyak pasien yang setelah menjalani operasi bedah saraf memerlukan ventilator akibat kerusakan saraf yang terjadi. Kondisi neurologis sebelumnya, secara langsung atau tidak langsung mempengaruhi kontrol pernapasan dan patensi jalan napas.

Kondisi yang terjadi selama operasi juga mempengaruhi, misalnya pada pasien dengan banyak manipulasi di daerah infratentorial dengan risiko terjadinya edema atau cidera brainstem yang disebabkan reseksi yang sulit. Jika terjadi manipulasi ekstensif di sekitar struktur medulla atau edema yang signifikan terjadi, maka ETT harus dipertahankan sampai pasien sadar, mengikuti perintah dam menunjukkan kembalinya refleks jalan napas. Risiko terjadinya hipoksemia dan hipokapnia juga berkurang, pasien memiliki waktu lebih untuk stabilisasi hemodinaika dan hemostasis. Sedasi dibutuhkan selama masa pemulihan ini. Oleh karena itu teknik ekstubasi awal harus dipertimbangkan secara individual dan harus didiskusikan dengan tim bedah saraf. ${ }^{12-14}$ Tidak ada konsensus yang menyatakan kapan dan pada pasien mana ekstubasi awal dapat dilakukan. Kondisi neurologis dan sistemik harus diperhatikan. Pada pasien ini karena operasi dilakukan pada regio pineal yang sangat dekat dengan brainstem dan cerebellum, dengan durasi 10 jam maka ekstubasi ditunda hingga pasien pulih sadar di ICU. Selama 
menunggu pasien pulih, sedasi dengan morfin dan midazolam diberikan. Banyak agen sedasi yang menjadi pilihan. Golongan opioid masih menjadi pilihan karena selain memiliki efek analgetik juga memiliki efek sedasi dan hipnotik. Hal yang tidak diinginkan dari penggunaan opioid adalah penurunan kesadaran, depresi napas dan miosis yang dapat mengganggu evaluasi neurologis dan menyebabkan hiperkarbia yang dapat meningkatkan TIK. Akan tetapi dengan menggunakan dosis kecil yang dititrasi, hal ini dapat dihindari. Dengan adanya obat reversal dari narkotika, yakni naloxone maka efek yang tidak diinginkan dapat diatasi dengan cepat. ${ }^{14,15}$

Midazolam yang merupakan golongan benzodiazepine merupakan agen sedasi yang paling sering digunakan di neuro ICU. Selain efek sedasi, efek anxiolysis dan amnesia antegrade yang dibutuhkan selama perawatan di neuro ICU juga merupakan property dari midazolam. Benzodiazepine tidak seperti opioid, tidak mempengaruhi perubahan tekanan darah atau laju nadi yang signifikan, pernapasan juga tidak terganggu. Tidak adanya efek analgesia, menjadikan opioid sering diberikan bersamaan dengan midazolam. Akan tetapi perlu diingat untuk menghindari pemberian dosis tinggi untuk menghindari agitasi dan delirium. ${ }^{14,15}$ Obat sedasi lain yang dapat digunakan adalah dexmedetomidine. Dexmedetomidine, agonis alpha 2, juga menjadi pilihan agen sedasi di neuro ICU. Sebagai agen yang dapat diberikan secara kontinyu, mudah dititrasi, memilik efek sedasi, anxiolysis, dan analgesia, tidak memiliki metabolit aktif, dan simpatolitik menjadikan agen ini semakin banyak digunakan di neuro ICU. Akan tetapi perlu diingat mengenai efek bradikardia dan hipotensi yang dapat terjadi. ${ }^{14,15}$ Analgetik yang diberikan pada pasien ini adalah Parecoxib. Parecoxib merupakan obat penghambat cyclooxygenase-2 (COX-2) selektif yang semakin banyak digunakan untuk analgesia pascaoperasi. Parecoxib bekerja dengan menghambat inflamasi dengan mengurangi pembentukan prostaglandin dengan menghambat aktivitas COX-2 di perifer dan sentral. Parecoxib tidak mempengaruhi agregasi trombosit sehingga mengurangi risiko perdarahan pascaoperasi.
Penggunaan parecoxib juga dapat mengurangi kebutuhan opioid pascaoperasi. Pengaruh lainnya adalah mengurangi risiko terjadinya postoperative cognitive dysfunction (POCD).${ }^{16-18}$

\section{Simpulan}

Kraniotomi posisi duduk memberikan lapang operasi yang optimal untuk reseksi tumor pineal pada kasus ini. Posisi duduk adalah standar emas untukposisi operasitumor di regiopineal dan tumor ventrikel empat, Keputusan untuk melakukan posisi duduk harus mempertimbangkan indikasi, kontraindikasi, kenyamanan dan familiaritas dari tim bedah dan anestesi di kamar operasi. Pemahaman tentang implikasi posisi duduk pada pasien penting untuk menjaga keselamatan pasien dan membuat operasi berjalan lancar. Pada kasus ini, operasi dengan posisi duduk dapat berjalan dengan baik tanpa adanya komplikasi, tidak terjadi komplikasi intraoperasi VAE ataupun komplikasi pascaoperasi lainnya.

\section{Daftar Pustaka}

1. Kennedy BC, Bruce JN. Surgical approaches to the pineal regio. Neurosurg Clin. 2011;22(3):367-80.

2. Lindroos A-C, Niiya T, Randell T, Romani R, Hernesniemi J, Niemi T. Sitting position for removal of pineal regio lesions: the Helsinki experience. World Neurosurg. 2010;74(45):505-13.

3. Ganslandt O, Merkel A, Schmitt H, Tzabazis A, Buchfelder M, Eyupoglu I, et al. The sitting position in neurosurgery: indications, complications and results: a single institution experience of 600 cases. Acta Neurochir (Wien). 2013;155(10):1887-93.

4. Dallier F, Di Roio C. Sitting position for pineal surgery: some anaesthetic considerations. Neurochirurgie. 2015;61(2-3):164-7.

5. Bisri T, Bisri DY. ABCDE Neuroanestesi prinsip dan teknik. Dalam: Anestesi untuk 
operasi tumor otak supratentorial dan infratentorial. Bandung: Fakultas Kedokteran Universitas Padjajaran; 2016. 1-40.

6. Goraksha S, Thakore B, Monteiro J. Sitting position in neurosurgery. J Neuroanaesth Crit Care. 2020;7(02):77-83.

7. Himes BT, Mallory GW, Abcejo AS, Pasternak J, Atkinson JLD, Meyer FB, et al. Contemporary analysis of the intraoperative and perioperative complications of neurosurgical procedures performed in the sitting position. $\mathrm{J}$ Neurosurg. 2016;127(1):182-8.

8. Gracia I, Fabregas N. Craniotomy in sitting position: anesthesiology management. Curr Opin Anesthesiol. 2014;27(5):474-83.

9. Schlichter RA, Smith D. Anesthetic management for posterior fossa surgery. Dalam: Cotrell JE, Patel P, Warner DS, editors. Neuroanesthesia. 6th ed. New York: Elsevier; 2017. 20-221.

10. Feigl GC, Decker K, Wurms M, Krischek B, Ritz R, Unertl K, et al. Neurosurgical procedures in the semisitting position: evaluation of the risk of paradoxical venous air embolism in patients with a patent foramen ovale. World Neurosurg. 2014;81(1):159-64.

11. Kurihara M, Nishimura S. Estimation of the head elevation angle that causes clinically important venous air embolism in a semi-sitting position for neurosurgery: a retrospective observational study. Fukushima J Med Sci. 2020;66(2):67-72.

12. Saringcarinkul A, Suwannachit S,
Punjasawadwong Y. Factors associated with operating-room extubation after emergency craniotomy. J Med Assoc Thai. 2016;99(8):933-9.

13. Cai Y, Zeng H-Y, Shi Z-H, Shen J, Lei Y-N, Chen B-Y, et al. Factors influencing delayed extubation after infratentorial craniotomy for tumour resection: a prospective cohort study of 800 patients in a chinese neurosurgical centre. J Int Med Res. 2013;41(1):208-17.

14. Bisri DY, Bisri T. Prinsip-prinsip neuroanestesi. Dalam: Dasar-dasar neuroanestesi. Bandung: Fakultas Kedokteran Universitas Padjadjaran; 2019. 50-2.

15. Watts CR, Kelley P. Sedation and analgesia in neurosurgery/neurocritical care. Contemp Neurosurg. 2016;38(13):1-6.

16. Paul BS, Paul G. Sedation in neurological intensive care unit. Ann Indian Acad Neurol. 2013;16(2):194.

17. Williams DL, Pemberton E, Leslie K. Effect of intravenous parecoxib on post-craniotomy pain. Br J Anaesth. 2011;107(3):398-403.

18. Huang S, Hu H, Cai Y-H, Hua F. Effect of parecoxib in the treatment of postoperative cognitive dysfunction: a systematic review and meta-analysis. Medicine (Baltimore). 2019;98(1).

19. Dunn LK, Naik BI, Nemergut EC, Durieux ME. Post-craniotomy pain management: beyond opioids. Curr Neurol Neurosci Rep. 2016;16(10):93. 